\title{
Enlightenment in Brazil Its Role in Ordering the Brazilian Nation from the Works of Cipriano Barata
}

\author{
Luiz Carlos Ferraz Manini
}

\author{
Master's Degree Student - Universidade Estadual de Londrina (Brazil)
}

E-mail: luiz_uel@yahoo.com.br

Doi:10.5901/mjss.2013.v4n11p327

\begin{abstract}
This work aims to analyze, through the work of the journalist Cipriano Barata, how was the absorption of Enlightenment ideas in the context of brazilian state's organization after its independence. In the early nineteenth century, Brazil became free of its colonial situation before Portugal, and the Enlightenment ideas, which arrived there through various filters and reinterpretations, served as a basis for ordering the new country. It's in this context that Cipriano Barata's work, which, among others, brought to the public context those political discussions which were based on this set of ideas, that helped in the huge transformations that were developed at that time.
\end{abstract}

Keywords: journalism, Cipriano Barata, Brazil at nineteenth century

\section{Introduction}

The independence and state-building are subjects whose studies in Brazil have proliferated quite generous since its establishment in the nineteenth century. Brazilian historiography was lavish in constructing interpretations of this event, viewing it from different perspectives, either as fact, by pointing the October 12th as foundational moment in Brazil, since in that day in 1822, D. Pedro I was proclaimed emperor; as building the September 7th as key to understanding of liberation against Portugal (especially after the abdication of the emperor, in 1831); or as a process, which would have given early in 1808, with the coming of Portuguese royal family to the country, in the context of the Napoleonic wars, and culminated with the formal separation, which dates can be put between the "Grito do Ipiranga" as the granting of the 1824 Constitution.

Such historiographical discussions point a path that has been trodden long, but about which we discussed more intensively in the 1970s and 1980s, when it proposed the so-called "linguistic turn" in the wake of the so called postmodernism , which bolstered the idea that history is, in particular, a narrative that is sustained by the real, but that would not be able to give account of it in its entirety. Thus, the many reinterpretations arising on certain events would be evidence that, apart from the "real", the discussion that takes place is about what the historian, endowed with scientific knowledge, recognized by their peers, and in possession of their sources, would able to build in order to convince the reader of a certain vision of the past. The works of Hayden White, Paul Veyne and Michel de Certeau, in the early 1970s, have started a supposed "crisis of history", by questioning what Chartier (2010) named as "epistemology of coincidence" (p. 12), in which what is told would be a reconstruction of what would have happened. This crisis might be interpreted as a construction of "modern historians" before the posture of the "post modern historians" because as stated by the French historian, "reconhecer as dimensões retórica ou narrativa da escritura da história não implica, de modo algum, negar-lhe sua condição de conhecimento verdadeiro, construído a partir de provas e controles "(p. 13) ${ }^{1}$. Thus, historians who resort to such a perspective have not seen a crisis in itself, which would disqualify the knowledge built by history, but they seek to highlight certain aspects given as "natural", within an epistemology of coincidence, in which the account would realize the reality last. What was stated was to emphasize how much interpretation is within what is called the historical account, which proposed to explain all of the past events like they were the reality itself. It may be affirmed that such an interpretation gives a different view about the text, which is understood more like a human construction than a objective materiality, in which the historian makes your own intentional construction. In the order hand, it has to be said that the pure discourse itself is not capable of constructing the reality, since we must pay attention at the place occupied

1 "recognizing the rhetoric or narrative dimensions in the history writing does not deny, in any way, its condition of true knowledge, built from evidence and controls" 
by who is talking about every interpretation.

Thus, discussing the independence and the construction of the Brazilian state does not appear as a mere rhetorical exercise, since it is based on socially constructed knowledge, accepted from a position of power occupied by the historian, which helps society to provide intellectually accounts with their past. Upon such positioning, we believe we build a possible version of what happened, trying to demonstrate a likelihood ratio between our report and the sources we have at our disposal. Likewise, we're not seeking a totalizing account, that could explain all aspects of the process that culminated in the liberation of Brazil before his Portuguese metropolis, but to indicate a possible path followed by the men who were engaged in this process.

Therefore, we find in the early nineteenth century Brazil a philosophical source available to that men at that time (the Enlightenment) and various characters who made use of these ideas in different perspectives, as well as through various means. One of these characters is a journalist, born at Bahia, called Cipriano Barata, editor of the Sentinel of Liberty, one of the many newspapers that circulated in Brazil at the time. We intend to analyze how, from the writings of the journalist, the Enlightenment permeated the construction of the Brazilian state, in the various discussions that took place in this context.

\section{Cipriano, His Newspaper and His Time}

Cipriano Barata figured as a typical man of Brazil in the late eighteenth and early nineteenth century. Born in 1762 at Bahia, a year before the transference the country's capital from Salvador to Rio de Janeiro, a fact that marked, among other events, an economic shift shaft in Brazil at the end of the century. In the transition from an agrarian economy, based on sugar cane, for a mining economy, the Northeast of the country had their political participation also decreased on the national scene. At the same time, an powerful white elite lived at Bahia, composed of a very small number of people, with a huge contingent of blacks and mulattos, priced out of basic rights by virtue of the existence of the slave regime. However, this distance was not definitive, because as shown by the reports about Conjuração Baiana in 1798, there was a relative movement of blacks in some white circles, which even helped in organizing the revolt.

It is through this movement, enshrined in history as the first "social revolution" of Brazil, as called Affonso Ruy (1978), which Cipriano Barata became visible to the eyes of power, when he was arrested and accused of being a leader of the movement. In the movement's wanton, Cipriano was accused of active participation in the formulation of the ideals of conjuration, although in later confrontations has vehemently denied such participation.

What interests us at the moment, however, are the factors that could have actually taken the future journalist to have been involved in this movement, despite its vigorous denial. One of the elements of great interest in the biography of Cipriano Barata is the fact that he studied at the University of Coimbra, Portugal, where he enrolled in 1786. According to studies by Marco Morel (2001), there Cipriano had enrolled in Philosophy, Mathematics and later in Medicine, leaving the university in 1790. It is of interest to note that the fact that he enrolled in different courses is part of a particular behavior of some members of the Brazilian intelligentsia at that time, that guided its formation under the Enlightenment principle of a broad education, but also focused on one special technical aspect, that was training of staff for the state bureaucracy. Thus, we realize that many of the men who participated in the Brazilian independence process were honed with this spirit, diffused from the university. This is the case, for example, about José Bonifácio, which would stand out later as a major Minister of D. Pedro I. Also formed at the University of Coimbra, Bonifácio served as minister, while writing a newspaper at Rio de Janeiro, and had previously written works of economic and technical nature, such as a publication on whaling in Brazil.

The University of Coimbra has undergone a makeover from the year 1772, set in a broader process of measures taken by the Marquis of Pombal. The marquis was Minister of D. José I, King of Portugal, but ended up concentrating himself all the administrative duties, within an absolutism context, but influenced by Enlightenment ideals that propagated through Europe. Thus, we can understand the stance of Pombal in what is conventionally called Enlightened Despotism, ie, a particular form of absolutist government mediated Enlightenment principles.

The Portuguese appropriation of the Enlightenment by the central power has developed from a perspective that is termed as Civil Empire, which was founded on the existence of a need of a government as a center for the conservation of rights, which would be preserved by making laws through the figure of the king. This same monarch should ensure the advancement of economy and science, in order to ensure the growth and wealth of his kingdom. This Portuguese reading of the Enlightenment was based on the ideas of the jurist Carlo di Martini, who served at the same time in the Austrian court, where he became known as Karl Anton von Martini. In this reading, are combined: the idea of rights and scientific advancement, dear to the Enlightenment, with the prominence of the central government, the cornerstone of 
absolutism, which would be the only one capable of ensuring the proper functioning of government and society.

It is in this context of reappropriated ideas that the University reform was made, which worked, thereafter, in its dissemination and in the new students training. However, we can not imagine that the readings made by the Brazilian students about this new reality has remained untouched, but were again reinterpreted through a filter of their colonial situation. It creates, according to what teaches Roger Chartier (2010), a new representation on the Enlightenment and its possibilities, because, although the speech has its own power and consistency, it also depends on the social place that is talked about. So it's not a mere exercise of recreation that was made by the students, but it's the only way we could realize how these ideias changed since its creation until its arrival in Brazil. This is how Cipriano Barata, like his contemporaries, end up being educated, making the Enlightenment ideas to be absorbed through countless retellings, before his return to the his country.

So this is how we return to the context of the Conjuração Baiana, in which Cipriano gained prominence as one of the accused in the movement's leadership. Since that was a movement that demanded the independence of the country as well as proposing a new social order, which would combat discrimination of color, we can infer that the presence of the ideas illustrated is striking, and these had been gestated in contact made from the studies developed in Coimbra. Also concerning the entry of Enlightenment ideas in Brazil, Katia Queiróz Mattoso edited a small book in 1969, which makes a survey of the works that made up the participants' libraries, sensing a presence of French ideas in Conjuration.

After his alleged involvement in the movement, his arrest and subsequent release in 1800, Cipriano Barata goes through a period in which there's no notes or events whose relevance could be documented. We must assume that, in the meantime, his performance has been more discreet, since his letters show that he became cane farmer, and continued working as a doctor. We also believe in the idea that this character had continued to spread his ideas about government and political situation in Brazil and Europe, since, at the time that unfolds in Portugal the movement know as Liberal Revolution of 1820 , Cipriano were elected as a representative of his province to compose the Cortes that were organized in the metropolis.

His performance as a deputy in the Cortes was marked by intense discussions with the Portuguese deputies, and even with the Brazilian representatives whose posture was aligned over the idea of continuing Brazil as a colony of Portugal. Once his claims have not been accepted, like his request for waiting the other Brazilian deputies which had not yet come to Portugal, Barata, followed by other companions, flees from Portugal towards Brazil.

On his arrival, Cipriano Barata settled in Pernambuco, in the year 1823, since their state was in the midst of conflict for independence. This is where his newspaper, Sentinela da Liberdade (Sentinel of Liberty), starts in April 1823. Its publication is inserted in the middle of a huge amount of journals that arise in the country after the fall of censorship in the changes context brought about by the revolution in Portugal. This scenario was quite conflictuous, like Isabel Lustosa showed when she studied this period, naming the relationships among the editors as a "war among journalists" (2000). It must be understood as the moment in which the public opinion had arose, bringing too many different ideas to be discussed, even with violence in some cases. It is through this newspaper that Cipriano gives greater visibility to his ideas, although we cannot ignore that, in the midst of a society with a vast amount of uneducated, other forms of appropriation and circulation of information has also had its role. Robert Darnton (2005) makes an important contribution towards understanding this reality in his text about Paris in the eighteenth century, to call it a "pioneer information society". What the American historian presents is the idea that, even in societies whose media are scarce, it creates circulation networks of information that assist in the dissemination of a variety of issues, which are constantly reviewed and rewritten. Thus, we cannot assume that the newspaper, despite its importance as a vehicle of communication, has been a privileged channel to the diffusion of ideas, like the Frankfurt school would had said. For we to have a more accurate view of the importance of the newspaper, it would be necessary, in addition to the assessment that we do now, also elaborate reception studies on such ideas, which does not fit within the limits of this article nor is it our intention. Thus, we intend to show how to work one of the links in this information chain that is created in Brazil in the nineteenth century, serving as a basis for further studies that will supplement or revise the same data presented here.

\section{The Enlightment Ideias in the Newspaper's Pages}

When we talk about the Enlightenment, there is a tendency to confuse this eighteenth century set of ideas with all the subsequent fate of Western culture, as stated by Robert Darnton (2005). In his view, the Enlightenment was a French phenomenon, specifically occurred in Paris, during a given time, developed by a limited number of philosophers (p.18). It can be seen with some clarity Darnton's exaggeration in claiming such reductionism, since this doctrine was not restricted to this country, but it has spread, with strength in other regions, such as Austria, Portugal and even Brazil. We 
agree with the idea that there wasn't, with the same prominence elsewhere, philosophers formulators similar ideas, but we can not deny how much of it spread around Europe and the world amidst various readings and appropriations.

In the Brazilian case, as noted, the entry of the illustrated ideas is given, with particular relevance, by the returning to the country of students whose previous studies had been done at European universities, especially in regard to the case of Coimbra. By going through such sites, the Enlightenment doctrine gained new aspects and even blended up with several theories that retook ancient teachings of the Portuguese monarchy, as pointed out by Eduardo Romero de Oliveira (p. 3), to discuss the formulation of the idea that had been developed in Portugal, which is the same notion diffused in Cipriano Barata's writings (2009), as we found when it says: "Vele V.M. para que os ministros não atentem contra as garantias sociais, como já têm feito contra as Leis, a segurança particular e a liberdade pública" (p. 242)².

This passage, published in a newspaper of May 21,1823, presents one of the possible readings that can extract than would the Enlightenment in its Brazilian version. Such movement preached, in its French origins, the predominance of reason as an instrument of knowledge of the world as one of its lines of force. By placing this same reason as a basic component of the human condition, eventually equalized all the men, giving them, according to the theory of John Locke, certain rights, which would be natural ${ }^{3}$. So when Cipriano refers to the king, is the sense that such rights must be respected, since they are essential and that not preserve them is an attack against the people. At the same time, one can realize that it is the king who must ensure these guarantees, because that is where the power resides, being the only one able to maintain the security and tranquility of the state, not allowing abuse or disregard for the laws. As a stay of the Old Regime, is the figure of the king that the journalist refers, keeping the tension between the old and the modern.

One can reaffirm such movement between the need of the king and the establishment of law that guarantees rights when the journalist states: " eu sou e quero ser de muito boa vontade Súdito (mas não vassalo) de nosso Imperador Constitucional Liberal D. Pedro I"(p. 252)4. The image of the king is held to affirm the desire to be subject, to be the one who obeys the laws and the government, as the doer of an order which does not want to subvert, but at the same time that the king should establish a commitment to the people to be guided in accordance with the laws, instituted and maintained by means of a constitution. This document reiterate the basic assumptions upon which society rests, in a liberal sense of preserving the essential conditions of human as well as we can still observe in passing another newspaper, published May 17, 1823: " eu desejo o Sistema constitucional do Império bem direito e firme. Desejo que nosso Imperador seja bem obedecido "(p. 237) 5 .

Elsewhere, we realize that there is still an effort to exempt from the figure of the king possible abuses and excesses that occur in government, attributing such errors to the ministers, that would be reckless and greedy, and badly advise the ruler, which should be attentive and vigilant to these excesses of his aides. Thus, the journalist would act towards a civic education, to show what are the defects and instruct the government, to lead the ruler and the people towards a better and more liberal coexistence, based on rational principles derived from the Enlightment. It is in this sense that we can understand when Cipriano says: " Mas eu hei de abrir os olhos do Nosso Adorado Imperador " ( $p$. $241)^{6}$, since the ministers are abusing the good faith of the emperor, and the journalist, educated man and builder of the public opinion, has the duty to assist in the smooth conduct of the government being run by King?

There're still other issues that we could quote, because of its actuality, which attention-grabbing in Cipriano Barata speech, as the discussion on press freedom, a theme dear to the journalist and running through several volumes of his work. Those would be more information in order to understand how the Enlightenment served, proposing solutions or paths that could be trod in the construction of the new independent nation, but that does not fit within the limits of an article.

\footnotetext{
2 "Watch Your Majesty for ministers not threaten social guarantees, as they have done against Laws, private security and public freedom"

${ }^{3}$ We could enlarge the discussion about the influence of John Locke's ideias in Cipriano Barata's works by remembering a passage which was published in May 25th, 1823: "the people in a revolution reassume its authority and its imprescriptible rights, and destroys his government, destroys the Kings, Laws and everything old to create the new, according to his Sovereign Will". This passage, which tell us about the Revolution ideia in his thoughts, can be seen as another example about the Enlightment incorporation in the Brazilian thought, but to discuss this, it'd be necessary just another paper.

4"I am and gladly want to be subject (but not a vassal) of our Liberal Constitutional Emperor D. Pedro I"

5 "I wish the Empire Constitutional System to be right and firm. I wish that our Emperor is well obeyed"

6 "But I shall open the eyes of Our Beloved Emperor"

${ }^{7}$ José Murilo de Carvalho, about this kind of behavior, would tell us "Not blaming the king and incriminating his counselors, in an attitude typical of the Old Regime" (2012, p.10). This could still confirm the circulation between the old and the new that was present not only in Cipriano Barata's works, but was quite spread among the journalists ideias.
} 


\section{Final Statements}

We should understand the Enlightenment as a movement that, although preached a fundamental idea of rationality as a guide to human existence and understanding of the world, presents itself multifaceted. Within the various perspectives presented by their thinkers, we can find many principles that were more or less appropriated and reinterpreted differently by the various places we passed by.

Thus we understand that in Brazil the discussions done by Cipriano Barata, through your newspaper, are not the only possibilities to understand how this theory came to the country, nor that this was the decisive interpretation that led the consolidation of the state and nation. They are indicative of a particular form of retelling, set in a broader context of discussions among journalists who have spoken at the time of independence of Brazil and the initial phase of nation building. We understand that Barata binds to a posture of liberal political ideals absorption, even though it's permeated by continuities of the Old Regime. At the same time, other journalists would write further, deepening such propositions in positions more radical or more conciliators, forming an immense kaleidoscope of political possibilities.

Concomitantly, the absorption the Enlightenment can be also seen through the encouragement to technical studies, in the development of a science that would serve to practical purposes, stimulating agriculture, manufacturing activities and trade, as Maria points Odila Days in his study "Aspectos da llustração no Brasil" (2009). Beyond what has materialized as a proposal of social or policy reforms, the historian bothered to check how the Enlightenment philosophical doctrine was translated into practical activities, within what was later called as instrumental rationality, a characteristic attributed in particular to the Nazi totalitarian regime ${ }^{8}$. We might say that such instrumental use of rational thought is not configured as a historical accident of the twentieth century, but was an integral part of the Enlightenment development as a practice in the places where it settled and diffused.

At the end we can say that the Enlightenment was a common basis from which emerged several branches, some more revolutionary, most other reformers, who in their confrontation through the press and other forms of information flow, assisted in the development of Brazil as nation and in building their state, in particular through the establishment of the first Constitution in 1824. In the particular case with what we deal briefly, we can see that Barata appropriated himself of certain elements of this discourse, in a Brazilian variation of French ideas ${ }^{9}$, which, through its dissemination through public opinion, helped to shape the nation that emerged in the early nineteenth century.

\section{References}

Anderson, B. (2008) Comunidades Imaginadas: reflexões sobre a origem e a difusão do nacionalismo. São Paulo: Companhia das Letras.

Barata, C. (2008) Sentinela da Liberdade e outros escritos (1821 - 1835). Organização e edição Marco Morel. São Paulo: EDUSP,.

Barros, M., Morel, M. (2003) Palavra, Imagem e Poder. o surgimento da imprensa no Brasil do século XIX. Rio de Janeiro: DP\&A.

Basile, M., Bastos, L. Carvalho, J.M. (2012). Às armas, cidadãos: panfletos manuscritos da independência do Brasil (1820 - 1823). São Paulo: Companhia das Letras; Belo Horizonte: Editora da UFMG.

BRIGGS, A., BURKE, P. (2006) Uma história social da mídia: de Gutenberg a Internet. 2. ed. Rio de Janeiro: Jorge Zahar Ed.

Chartier, R. (2010) A história ou a leitura do tempo. 2. ed. Belo Horizonte: Autêntica Editora.

Darnton, R. (2005) Os dentes falsos de George Washington: um guia não convencional para o século XVIII. São Paulo: Companhia das Letras.

Dias, M. O. L. S.(2009) A interiorização da metrópole e outros estudos. 2. ed. São Paulo: Alameda.

Leite, R. L. (2000) Republicanos e Libertários: pensadores radicais no Rio de Janeiro (1822). Rio de Janeiro: Civilização Brasileira.

Luca, T. R., Martins, A. L. (Eds) (2011) História da Imprensa no Brasil. São Paulo: Contexto, 2011.

Lustosa, I. (2000) Insultos Impressos: a guerra dos jornalistas na Independência (1821 - 1823). São Paulo: Companhia das Letras.

Martin-Barbero, J. (1997) Dos meios as mediações: comunicação, cultura e hegemonia. Rio de Janeiro: Editora UFRJ.

Melo, J. M. (2003) História Social da Imprensa: fatores socioculturais que retardaram a implantação da imprensa no Brasil. Porto Alegre: EDIPUCRS.

Morel, M. (2001) Cipriano Barata na Sentinela da Liberdade. Salvador: Academia de Letras da Bahia; Assembleia Legislativa do Estado da Bahia.

Oliveira, C. H. L. S. (1999) A astúcia liberal: relações de mercado e projetos políticos no Rio de Janeiro (1820 - 1824). Bragança

${ }^{8}$ That was the main criticism of the Frankfurt School to the Enlightenment, because these ideas, instead of freeing the man and remove him from his minority, as Kant hoped, become man a propaganda slave, whether political or simply shopping, taking him to believe in any political regime, as happened in Nazi Germany.

${ }^{9}$ We talk about the Enlightment as a French movement, but it must be clear that there were a lot of different ideias, like the ones which came from England, that helped to shape the thought of the Brazilian journalists at the early nineteenth century. 
Paulista: EDUSF e ÍCONE.

Oliveira, Eduardo R. A idéia de Império e a fundação da Monarquia Constitucional no Brasil (Portugal - Brasil, 1772 - 1824). In Tempo. n. 18, v. 1, pp. 43 - 63

Ruy, A. (1978) Primeira Revolução Social Brasileira. 2. Ed. São Paulo: Ed. Nacional.

Sodré, Nelson W. (1973) História da Imprensa no Brasil. 4. ed. Sã 